\title{
Christian Yoga: Something New Under the Sun/Son?
}

\author{
CANDy Gunther Brown
}

Between the 1960s and 2010s, yoga became a familiar feature of American culture, including its Christian subcultures. This article examines Christian yoga and publicschool yoga as windows onto the fraught relationship between Christianity and culture. Yoga is a flashpoint for divisions among Christians and between them and others. Some evangelicals and pentecostals view yoga as idolatry or an opening to demonic spirits; others fill gaps in Christian practice by using linguistic substitution to Christianize yoga. In 2013, evangelical parents in California sued the Encinitas Union School District (EUSD) for promoting Hinduism through Ashtanga yoga. Sedlock v. Baird's failure to dislodge yoga exposes tensions in Christian anti-yoga and pro-yoga positions that stem from a belief-centered understanding of religion, the dissatisfaction of many Americans with Protestant dominance in cultural institutions, and a broad-based pursuit of moral cultivation through yoga spirituality. I argue that, although many evangelicals feel like an embattled minority, they are complicit in cultural movements that marginalize them. Nä̈veté about how practices can change beliefs may undercut Christian doctrines, facilitate mandatory yoga and mindfulness meditation in which public-school children and teachers are required to participate, and impede evangelistic goals by implicating Christians in cultural appropriation and cultural imperialism.

$667 \begin{aligned} & \text { HEATON College believes offering yoga courses contributes to } \\ & \text { the college mission to serve Jesus Christ and advance His } \\ & \text { Kingdom by educating the whole person through a redeemed }\end{aligned}$
form of yoga that addresses physical, emotional and spiritual needs." In

This article was presented as the presidential address to the American Society of Church History on January 6, 2018. It builds on my research for two books: The Healing Gods: Complementary and Alternative Medicine in Christian America (New York: Oxford University Press, 2013); and a forthcoming book, Debating Yoga and Mindfulness in Public Schools: Reforming Secular Education or Reestablishing Religion? (Chapel Hill: University of North Carolina Press, 2019). I wish to thank the following individuals for helpfully commenting on previous drafts: Chris Armstrong, Peggy Bendroth, Josh Brown, Elesha Coffman, Roger Corbin, Heather Curtis, Bruce Hindmarsh, Mark Noll, Randi Walker, and Adrian Weimer. The article title alludes to Ecclesiastes 1:9 (NIV): "What has been will be again, what has been done will be done again; there is nothing new under the sun."

Candy Gunther Brown is Professor of Religious Studies at Indiana University, Bloomington. 
2015, Wheaton issued a four-page position statement to reassure fellowevangelicals that the College has redeemed yoga from its non-Christian roots. Yoga needed redemption because it is "undeniably rooted in Hinduism" and because "one common postural sequence, the Sun Salutation (Sanskrit: Surya Namaskara), originated as worship to the solar deity, Surya." What redeems yoga at Wheaton is, first, that it is taught by Christians who have signed the Wheaton College Statement of Faith. Second, instructors subtract "ancient (and sometimes religious) words" from pose descriptions and add Christian belief statements: at the start or end of class, they "lead a prayer, offer Scripture or a word of spiritual encouragement." Although offered by the Athletics Department, Wheaton envisions yoga as more than exercise. Quoting an arsenal of biblical proof texts, Wheaton argues that yoga helps Christians "be still" in God's presence (Psalm 46:10), avoid being "anxious" (Matthew 6:25-27), and manifest "fruit of the Spirit" (Galatians 5:22-23). Wheaton yoga looks a lot like traditional yoga. Classes begin sitting "cross-legged" (in Padmāsana, or Lotus) to "find mental stillness." The next " $30-50 \%$ of a class" consists of Sürya Namaskāras; the Wheaton brochure labels some poses in English and others in Sanskrit-for instance, "Mountain," "Chaturanga," and "Downward Dog." Classes end with "Savasana, or Corpse." Although implying that the substitution of English and Christian language redeems yoga from Hinduism, Wheaton adopts the same pose sequences and even some terms from "unredeemed" yoga. ${ }^{1}$

This article considers what the cultural mainstreaming of yoga and meditation, including Christian yoga and public-school yoga, reveals about the relationship between Christianity and American culture. Prior to the 1960s, yoga was culturally marginal in the United States. Polls show a steady rise from three percent of Americans practicing yoga in 1976 to fifteen percent in $2016 .^{2}$ Yoga is often marketed as a scientifically validated, secular technique for cultivating beautiful, physically fit bodies. Indeed, many practitioners see yoga as a purely physical activity. Nevertheless, a

\footnotetext{
1"Yoga at Wheaton?," Wheaton College, January 2015, https:/www.wheaton.edu/media/ athletics/Why-Yoga-at-Wheaton.pdf.

${ }^{2}$ Gallup Poll, 1976, quoted in Stefanie Syman, The Subtle Body: The Story of Yoga in America (New York: Farrar, Straus, and Giroux, 2010), 256; and Yoga Journal and Yoga Alliance with Ipsos Public Affairs, The 2016 Yoga in America Study Conducted by Yoga Journal and Yoga Alliance, 2016 (hereafter cited as Yoga-2016), http://media.yogajournal.com/wp-content/uploads/2016Yoga-in-America-Study-Comprehensive-RESULTS.pdf, 2, 10. Yoga-2016 cites "spiritual development" as an initial motive for 24 percent and an ongoing motive for 23 percent of respondents. A similar 2012 study reported that "spiritual development" motivates 31.7 percent of Americans to start yoga and keeps 30.4 percent practicing. "Yoga in America-2012," Yoga Journal with Sports Marketing Surveys USA, http://www.mynewsdesk.com/material/ pressrelease/876659/download?resource_type=resource_attached_pdf_document.
} 
quarter of American practitioners cite "spiritual development" as a goal. ${ }^{3}$ Half of all instructors are certified by the Yoga Alliance, which requires studying "yoga philosophies and traditional texts (such as the Yoga Sutras, Hatha Yoga Pradipika or Bhagavad Gita)" that are widely associated with Hinduism, among other traditions. Certification covers "yoga lifestyle, such as the precept of non-violence (ahimsa), and the concepts of dharma and karma," "energy anatomy ... (chakras, nadis)," and "chanting, mantra, [and] meditation.",

Yoga exemplifies significant flows and rifts in American culture, including its Christian subcultures. Many Americans who resent Protestant dominance in cultural institutions such as public schools envision yoga spirituality as a preferable option for moral cultivation. Certain evangelicals and pentecostals view yoga as idolatry or an opening to demonic spirits. Other Christians, among them Catholics and mainline Protestants, use yoga to fill gaps in Christian practice. ${ }^{5}$ I find it particularly revealing to examine the evangelical strategy of Christianizing yoga through linguistic substitution. Conversely, in 2013, evangelical parents in California, Jennifer and Stephen Sedlock, sued the Encinitas Union School District (EUSD) for promoting Hinduism through Ashtanga yoga. Sedlock v. Baird's failure to dislodge yoga exposes tensions in Christian anti-yoga and pro-yoga positions that stem from a belief-centered understanding of religion. ${ }^{6}$

I argue that, although many evangelicals feel like an embattled minority, they are complicit in cultural movements that marginalize them. This article makes three claims. First, naïveté about how practices can change beliefs may undercut evangelical doctrines as Christian yoga practitioners potentially experience subtle shifts in worldview. Second, evangelicals' ineffective resistance to or support of public-school yoga and mindfulness meditation may facilitate mandatory programs in which children and teachers are required to participate. Third, Christians may impede their evangelistic goals by making themselves vulnerable to charges of cultural appropriation and cultural imperialism.

This article begins by historically contextualizing Christian yoga as the latest instance of a recurrent struggle to navigate between Christ and culture. The article compares yoga to fiction, music, and aerobics, interrogates

\footnotetext{
${ }^{3}$ Yoga-2016, 54.

${ }^{4}$ Ibid., 64; and "Spirit of the Standards - RYS 200," Yoga Alliance, July 2016, https://www. yogaalliance.org/credentialing/standards/200-hourstandards.

${ }^{5}$ For liberal Protestant adoption of yoga, see Pamela Klassen, Spirits of Protestantism: Medicine, Healing, and Liberal Christianity (Berkeley: University of California Press, 2011), xxii. For Catholic positions, see notes 28, 29, and 44 below.

${ }^{6}$ Sedlock v. Baird, Superior Court of San Diego County, No. 37-2013-00035910-CU-MC-CTL (2013), 235 Cal. App. 4th 874 (2015).
} 
evangelical assumptions about beliefs and practices, and assesses why and how yoga divides Christians. It then examines nominally secular, public-school yoga through a case study of Ashtanga yoga. Finally, it considers how Christian and secular yoga may exacerbate intercultural tensions.

\section{Christianity and Culture: Fiction, Music, Aerobics-and YoGA}

In 1951, the theologian H. Richard Niebuhr identified an "enduring problem" in the relationship between "Christ and culture" as Christians strive to live "in the world" without being "of the world." " Self-identified evangelicals imagine themselves avoiding the poles of cultural withdrawal or assimilation of worldly values, instead balancing purity from and presence in the world. ${ }^{8}$ Evangelicals characteristically adapt cultural resources for Christian purposes. Historically, evangelicals have often debated whether certain cultural products are inherently corrupting. Two notable examples are fiction and music.

Into the mid-nineteenth century, many evangelicals worried that fiction was too dangerous to touch. In the 1856 book Religious Novels: An Argument Against Their Use, Charles Wesley Andrews laments that the best novelists brought in the Trojan "horse," since preaching "truth through fiction" is no better than promoting "temperance through rum." Godly texts engage intellectual interest to provoke moral action. But novels, like rum, "hurl" readers into the "fire of consuming passion, and then, at last, into the fire which is unquenchable." ${ }^{, 10}$ Evangelicals gradually became more comfortable with novels, publishing bestsellers such as Harriet Beecher Stowe's Uncle Tom's Cabin (1852), Charles Sheldon's In His Steps (1896), and Tim LaHaye and Jerry Jenkins's Left Behind (1995).

A similar story can be told of evangelicals' halting acceptance of popular music. Protestant reformers like John Calvin worried that the writing of extra-biblical hymns and Psalm paraphrases introduced heresy into the church. Eighteenth- and nineteenth-century revivals spread as innovators such as Isaac Watts, Charles Wesley, Fanny Crosby, and Ira Sankey wrote hymns, even very occasionally putting Christian lyrics to popular drinking

\footnotetext{
${ }^{7}$ H. Richard Niebuhr, Christ \& Culture (New York: Harper \& Row, 1951), 1; and John 17: 14-16 (NIV).

${ }^{8}$ Candy Gunther Brown, The Word in the World: Evangelical Writing, Publishing, and Reading in America, 1789-1880 (Chapel Hill: University of North Carolina Press, 2004), 1-7.

${ }^{9}$ Charles Wesley Andrews, Religious Novels: An Argument Against Their Use (New York: A. D. F. Randolph, 1856), 25.

10“"The Need of Pure Literature," AME Church Review 8 (October 1891): 229-230; and Brown, Word in the World, 96-97.
} 
tunes. As Salvation Army founder William Booth famously-though not originally-quipped: "Why should the devil have all the best tunes?",11

The phenomenon of Contemporary Christian Music (CCM) is the "offspring" of an unlikely "mating" of rock and roll youth culture with the Jesus Movement of the 1960s-1970s. Older Christians objected that rock music, and especially loud drums and electric guitars, are inherently evil. The founder of Sparrow Records, Billy Ray Hearn, notes a pattern: "When something new comes along, the church usually rejects it; then they tolerate it; then it becomes acceptable; and, finally, it becomes traditional." 12 Churches initially viewed Christian fiction, Christian music, and Christian yoga with suspicion, and Christians who wanted to participate had to justify their choices. Over time, participation was normalized.

Christian alternatives allow Christians both to participate in and view themselves as purer than popular culture. In their study of CCM, sociologists Jay Howard and John Streck observe that Christian variants permit subcultures to "define themselves as somehow separate from the wider culture," even if they share economic, social, and religious formations. ${ }^{13}$ In 2016, Americans spent $\$ 16$ billion on yoga classes, clothing, and accessories. $^{14}$ Christian products fill a market niche. As the cultural commentator South Park noted in 2003: Christian producers have a "built-in audience." 15

The development of Christian yoga is in certain respects nothing new. It may be viewed as a subgenre of a Christian diet, fitness, and therapeutic self-help market that, as the ethnographer Marie Griffith argues, reflects a white, middle-class, American Protestant valorization of bodily health and beauty as spiritual virtues. ${ }^{16}$ When aerobics emerged as the fitness craze of the 1970s-1980s, Christians jumped in energetically, branding their own products. As yoga surpassed aerobics in popularity, Christian yoga (perhaps inevitably) followed.

Is Christian yoga comparable to Christian fiction, Christian music, and Christian aerobics? All of these movements are appealing for similar

\footnotetext{
${ }^{11}$ Jay R. Howard and John M. Streck, "The Splintered Art World of Contemporary Christian Music," Popular Music 15, no. 1 (January 1996): 39. The English evangelist Rowland Hill (1744-1833) asked this question before Booth: Christopher R. Armstrong, "Tavern Tunes in Church Music and "Why Should the Devil Have All the Good Music?," Grateful to the Dead, updated November 2, 2009, https:/gratefultothedead.wordpress.com/2009/11/02/tavern-tunes-inchurch-music-and-why-should-the-devil-have-all-the-good-music/.

${ }^{12}$ Billy Ray Hearn, quoted in Howard and Streck, "Splintered Art World," 39.

${ }^{13}$ Howard and Streck, "Splintered Art World," 37.

${ }^{14}$ Yoga-2016, 4.

${ }^{15}$ South Park, season 7, episode 9, "Christian Rock Hard," directed and written by Trey Parker, aired October 29, 2003.

${ }^{16}$ Marie Griffith, Born Again Bodies: Flesh and Spirit in American Christianity (Berkeley: University of California Press, 2008), 2, 4, 13.
} 
reasons: they invite experiential, physically engaged and/or emotionally rich encounters with God. ${ }^{17}$ They each reflect a belief-centered understanding of religion, which breeds confidence that meanings can be transformed by emptying and refilling neutral containers with Christian linguistic content, much like substituting ingredients in a recipe. This article contends that, despite these similarities, Christian yoga is more of a stretch theologically and culturally, myopic about the potential for practices to change beliefs, and prone to charges of cultural appropriation and cultural imperialism.

\section{Practices Change Beliefs}

Evangelicals identify a "Christian" as one who believes and tells others the Gospel. A favorite Bible verse is Romans 10:9 (NIV): "If you declare with your mouth, 'Jesus is Lord,' and believe in your heart that God raised him from the dead, you will be saved." If right beliefs constitute the core of true religion, one's intent in performing practices largely determines whether or how those practices are religious. This doctrinal view is naive to how practices might transform beliefs, whether through metaphysical or material mechanisms. $^{18}$

Certain Hindu yoga proponents express an experiential view of religion based on metaphysical assumptions of how practices change beliefs. The Hindu American Foundation argues that "even when Yoga is practiced solely as exercise, it cannot be completely delinked from its Hindu roots" because assanas, or postures, have "psycho-spiritual effects." 19 Specifically, "yoga, like its Hindu origins does not offer ways to believe in God; it offers ways to know God"; āsanas lead practitioners along the "path of self-realizationthat each individual is a spark of the divine. Expect conflicts if you are sold on the exclusivist claims of Abrahamic faiths." ${ }^{20}$ Hinduism Today's managing editor, Sannyasin Arumugaswami, predicts that "a Christian trying to adapt these practices will likely disrupt their own Christian beliefs." ${ }^{21}$

\footnotetext{
${ }^{17}$ Christopher R. Armstrong, "Sound, Style, Substance: New Directions in Evangelical Spirituality," in The Future of Evangelicalism in America, ed. Candy Gunther Brown and Mark Silk (New York: Columbia University Press, 2016), 61.

${ }^{18}$ For an evangelical call to attend to practice, see James K. A. Smith, You Are What You Love: The Spiritual Power of Habit (Grand Rapids, Mich.: Brazos, 2016).

${ }^{19}$ Swaminathan Venkataraman, quoting B. K. S. Iyengar, in "Disguised Hinduphobia," Open Magazine, updated March 7, 2011, http://www.openthemagazine.com/article/world/disguisedhinduphobia\#all.

${ }^{20}$ Aseem Shukla, "Yoga: Stolen from the Hindus," Washtington Post, printed in Pittsburgh PostGazette, April 25, 2010, http://www.post-gazette.com/opinion/Op-Ed/2010/04/25/Yoga-stolenfrom-the-Hindus/stories/201004250220.

${ }^{21}$ Sannyasin Arumugaswami, quoted in “'Christian Yoga' Strikes a New Pose," The Denver Post, May 13, 2006, http://www.denverpost.com/2006/05/13/christian-yoga-strikes-a-new-pose/.
} 
One need not accept metaphysical reasoning to make an empirical observation that long-term yoga practice correlates with heightened spirituality. A U.S. nationwide survey by psychologist Crystal Park reported in 2016 that 62 percent of yoga students $(\mathrm{n}=360)$ and 85 percent of teachers $(n=156)$ changed their primary reason for practice. The primary motive typically transitioned from "exercise and stress relief" to "spirituality." Of students reporting a change, spirituality became the primary motive for 24 percent and an additional motive for 48 percent; 50 percent of teachers attested that spirituality became their primary motive, and the remaining 50 percent came to identify spirituality as an additional motive. ${ }^{22}$ A 2005 study found that longer-term yoga practitioners were less likely to identify as Christian and more likely to identify as "Spiritual but Not Religious" or Buddhist. ${ }^{23}$ Other studies suggest that "a shift seems to take place," leading practitioners to "a whole new spiritual awareness and totally identifying with the yoga philosophy." "24 Take for example Kristin, a young woman from Indiana who grew up Catholic and tried yoga in college "starting with the physical aspects." Kristin sensed no religious conflict because "they have yoga classes at the YMCA and that's a Christian organization." Kristin came to see the "eight limbs of Ashtanga Yoga" - the eighth of which is samädhi, defined in Ashtanga as becoming "one with God"-as "basically similar to the Ten Commandments" only better because they were "just like suggestions," unlike rule-oriented Christianity. ${ }^{25}$

My forthcoming book, Debating Yoga and Mindfulness in Public Schools, accounts for such data by articulating a theory to explain how embodied practices, such as yoga and mindfulness meditation, might affect religious and spiritual experiences. Research on language, embodiment, and perception suggests that sensory and affective experiences of practicing yoga or mindfulness and participating in practice communities shape perception through interplay of: heightened awareness of sensory experiences; reinterpretation of experiences through the lens of assumptions and values communicated; and

\footnotetext{
${ }^{22}$ Crystal L. Park, Kristen E. Riley, Elena Bedesin, and V. Michelle Stewart, "Why Practice Yoga? Practitioners' Motivations for Adopting and Maintaining Yoga Practice," Journal of Health Psychology 21, no. 6 (June 2016): 887, 891.

${ }^{23}$ Stephen Penman, Marc Cohen, Philip Stevens, and Sue Jackson, "Yoga in Australia: Results of a National Survey," International Journal of Yoga 5, no. 2 (2012): 91-101; and cf. Arndt Büssing, Anemone Hedtstück, Sat Bir S. Khalsa, Thomas Osterman, and Peter Heusser, "Development of Specific Aspects of Spirituality During a 6-Month Intensive Yoga Practice," Evidence-Based Complementary and Alternative Medicine (2012): 1-7.

${ }^{24}$ Sabine Henrichsen-Schrembs, "Pathways to Yoga-Yoga Pathways: Modern Life Courses and the Search for Meaning in Germany" (PhD diss., University of Bremen, 2008); and HenrichsenSchrembs \& Peter G. A. Versteeg, "A Typology of Yoga Practitioners: Towards a Model of Involvement in Alternative Spirituality," Practical Matters 4 (1 March 2011): 12.

25"Kristin," quoted in Michael Metroka, "Avoiding the Perils of Isomorphism: A Case Study of a Yoga Studio" (unpublished manuscript, March 5, 2010), Indiana University, appendix.
} 
cultural associations that remain available after subtracting religious language. ${ }^{26}$ Because embodied, regularly repeated, and emotionally charged, such practices may be more efficacious than doctrinal teachings in conveying and reinforcing religious meanings.

Doctrinal interpretations of religion notwithstanding, few Christian commentators argue that yoga is a purely physical practice. What they disagree over is whether yoga spirituality is antagonistic or complementary to Christianity.

\section{Christian Concerns about Yoga}

Polls report that 9 percent of Americans who have not tried yoga, and 4 percent of those who stopped, give the reason: "The 'spirituality' aspect of the practice bothers me." ${ }^{27}$ Catholic doctrinal statements warn against confusing the pleasing sensations of yoga and Eastern meditation with the Holy Spirit. ${ }^{28}$

\footnotetext{
${ }^{26}$ Brown, Debating Yoga and Mindfulness, develops this argument, drawing, for example, on: Sarah Coakley, ed., Religion and the Body (Cambridge: Cambridge University Press, 1997); Colleen McDannell, Material Christianity: Religion and Popular Culture in America (New Haven, Conn.: Yale University Press, 1995), 2; Albert Silverstein, "Unlearning, Spontaneous Recovery, and the Parital-Reinforcement Effect in Paired-Associate Learning," Journal of Experimental Psychology 73, no. 1 (1967): 15-21; Edith Wyschogrod, "Doing Before Hearing: On the Primacy of Touch," in Textes pour Emmanuel Levinas, ed. François Laruelle (Paris: JeanMichel Place, 1980), 179-203; Catherine Bell, Ritual Theory, Ritual Practice (New York: Oxford University Press, 1992); Mark Paterson, The Senses of Touch: Haptics, Affects, and Technologies (New York: Berg, 2007); Maurice Merleau-Ponty, The Phenomenology of Perception, trans. Colin Smith (New York: Humanities Press, 1962); Lawrence E. Sullivan, Body Works: Knowledge of the Body in the Study of Religion (Chicago: University of Chicago Press, 1990); Richard Schechner, Performance Theory (New York: Routledge, 2003); Ariel Glucklich, Sacred Pain: Hurting the Body for the Sake of the Soul (New York: Oxford University Press, 2001); Constance Classen, Worlds of Sense: Exploring the Senses in History and across Cultures (New York: Routledge, 1993); David Chidester, "Haptics of the Heart: The Sense of Touch in American Religion," Culture and Religion 1, no. 1 (May 2000): 61-84; Juhani Pallasmaa, The Eyes of the Skin: Architecture and the Senses, 3rd ed. (Hoboken, N.J.: Wiley, 2012); Lawrence W. Barsalou, Aron K. Barbey, W. Kyle Simmons, and Ava Santos, "Embodiment in Religious Knowledge," Journal of Cognition and Culture 5, no. 1 (2004): 1458, 14, 43-44; Tamer M. Soliman, Kathryn A. Johnson, and Hyunjin Song, "It's Not 'All in Your Head': Understanding Religion From an Embodied Cognition Perspective," Perspectives on Psychological Science 10, no. 6 (November 1, 2015): 852-864, 853, 857; and Ilan Kutz, Joan Z. Borysenko, and Herbert Benson, "Meditation and Psychotherapy: A Rationale for the Integration of Dynamic Psychotherapy, the Relaxation Response, and Mindfulness Meditation," American Journal of Psychiatry 142, no. 1 (January 1985): 4.

${ }^{27}$ Yoga-2016, 41.

${ }^{28}$ Congregation of the Doctrine of the Faith (Joseph Cardinal Ratzinger, later Pope Benedict XVI), Letter to the Bishops of the Catholic Church on Some Aspects of Christian Meditation (Vatican City: United States Catholic Conference, 1989), 28: "Some physical exercises automatically produce a feeling of quiet and relaxation, pleasing sensations, perhaps even phenomena of light and of warmth. . . . To take such feelings for the authentic consolations of the Holy Spirit would be a totally erroneous way of conceiving the spiritual life. Giving them a
} 
Pope Francis cautions: "You can take . . . a million courses in yoga, [and] Zen ... but all of this will never be able to give you the freedom" of God's love. $^{29}$ Evangelicals lack unified theological authority structures. ${ }^{30}$ Individuals who object to yoga cite at least one of two reasons. First, they worry about "idolatry"- prayer to or worship of gods other than Yahweh, contrary to the Bible's first commandment: "You shall have no other gods before me." ${ }^{31}$ The Old Testament cautions against emulating how other cultures petition their gods: "You must not worship the LORD your God in their way." 32 The New Testament forbids reverencing images of "birds and animals and reptiles." ${ }^{, 33}$ Christian critics worry that Sürya Namaskāra developed as a prayer to the solar deity, Surya, and that many postures emulate animals associated with divine beings. ${ }^{34}$ Evangelical Marcia Montenegro argues that "'Christian Yoga' is an oxymoron. . . . Just as there is no Christian Ouija board and no Christian astrology, so there is no Christian Yoga that is either truly Yoga or truly Christian."35

Pentecostal and charismatic Christians may express a second concern: that yoga postures and breathing techniques invite spirits other than the Holy Spirit to occupy the bodies of practitioners, causing physical and spiritual harm. ${ }^{36}$ Pentecostal and former yoga instructor Corinna Craft envisions Sun Salutations as a "moving liturgy, an embodied form of worship" that incorporates acts of "bowing," "petition," "receiving and surrender," and "thanksgiving," and functions as a "full-body sign language to the spirit realm, beckoning or inviting spirits to respond and engage in the

symbolic significance typical of the mystical experience, when the moral condition of the person concerned does not correspond to such an experience, would represent a kind of mental schizophrenia which could also lead to psychic disturbance and, at times, to moral deviations." Pontifical Council for Culture and Pontifical Council for Interreligious Dialogue, Jesus Christ the Bearer of the Water of Life: A Christian Reflection on the "New Age" (Strathfield: St. Paul's, 2002), 2.3.4.1, contrasts "Christian faith" with "New Age" practices, such as "yoga, zen, transcendental meditation and tantric exercises [that] lead to an experience of self-fulfilment or enlightenment."

${ }^{29}$ Pope Francis, quoted in Carol Glatz, "Catechism, Yoga, Zen Cannot Open People's Hearts to God, Pope Says," Catholic News Service, January 9, 2015, http://www.catholicnews.com/services/ englishnews/2015/catechism-yoga-zen-cannot-open-people-s-hearts-to-god-pope-says.cfm.

${ }^{30}$ Molly Worthen, Apostles of Reason: The Crisis of Authority in American Evangelicalism (New York: Oxford University Press, 2014).

${ }^{31}$ Exodus 20:3 (NIV).

${ }^{32}$ Deuteronomy 12:31 (NIV).

${ }^{33}$ Romans 1:22-23 (NIV).

${ }^{34}$ Sri K. Pattabhi Jois, Surya Namaskara (New York: Ashtanga Yoga New York, 2005), 7, 38, 10, $45,11,10$.

${ }^{35}$ Marcia Montenegro, "Christian Yoga: An Oxymoron?," Christian Answers for the New Age, updated December 2009, www.christiananswersforthenewage.org/Articles_ChristianYoga.html.

${ }^{36}$ Matt. 12:43-45; and I Cor. 6:19-20. 
practitioner's life." ${ }^{37}$ For Craft, it does not matter whether the practitioner "knows or agrees" with these meanings because "practice constitutes consent," in the sense that "doing is the action of agreeing." Consequently, "practice attracts and engages spirits" who "co-authored" yoga. ${ }^{38}$ Historic roots matter because "authorship implies ownership" and "ownership implies right of possession and control." Craft continues:

The spirit realm knows what belongs to it. Just as a stolen Lexus can be traced back to its rightful owner even if the thief removes the license plate and re-upholsters the interior . . . so, too, yoga misappropriated by naive westerners can be traced back to Hindu spirits who are not fooled by a little revamping. They've got the serial number and title deed, so to speak. They'll get back in their vehicle while you're driving it. ${ }^{39}$

By this logic, Christians do not own yoga and have no right to remove religion from or repurpose yoga as Christian. Nevertheless, Christian yoga is on the rise.

\section{Christian Yoga}

A 1998 survey reported that most American yoga practitioners were collegeeducated, urban, non-Christian women. ${ }^{40}$ Ten years later, Christians had joined the ranks of self-described American yogis. A 2007 Christianity Today poll found that 4 percent of those "less active" in church and 2 percent of those "more active" used yoga to "grow spiritually." 41 Christians are still less likely than other Americans to participate. A 2013 survey noted that 73 percent of practitioners in Austin, Texas, view yoga as a "spiritual activity." 42 Although respondents came from multiple religions, there were fewer Christians and more religious "nones" and "others"; only 41 percent identified as Christian (by comparison, 48 percent of Austin's population has a Christian affiliation). There is a gap between Christians and other practitioners, but it is narrow.

\footnotetext{
${ }^{37}$ Corinna Craft, "Renunciation," What's the Matter with Yoga? (blog), WordPress, accessed August 13, 2018, https://whatsthematterwithyoga.wordpress.com/renunciation/.

${ }^{38}$ Corinna Craft, "Resources," What's the Matter with Yoga? (blog), WordPress, accessed August 13, 2018, https://whatsthematterwithyoga.wordpress.com/resources/.

${ }^{39}$ Corinna Craft, "My Epic Deliverance," What's the Matter with Yoga? (blog), WordPress, accessed August 13, 2018, https://whatsthematterwithyoga.wordpress.com/home/.

${ }^{40}$ Robert B. Saper, David M. Eisenberg, Roger B. Davis, Larry Culpepper, and Russell S. Phillips, "Prevalence and Patterns of Adult Yoga Use in the United States: Results of a National Survey," Alternative Therapies in Health and Medicine 10, no. 2 (March/April 2004): 44.

${ }^{41}$ Sam O'Neal, "Yoga Is a Stretch," Christianity Today (Spring 2007), http://www. christianitytoday.com/pastors/2007/spring/15.11.html.

${ }^{42}$ Mary T. Quilty, Robert B. Saper, Richard Goldstein, and Sat Bir S. Khalsa, "Yoga in the Real World: Perceptions, Motivators, Barriers, and Patterns of Use," Global Advances in Health and Medicine 2, no. 1 (January 2013): 44, 45, 47, 48.
} 
Some Christians are attracted to practices adapted from Asian religions because of the spiritual benefits. Christians may turn to yoga to fill lacunae in Christian traditions - which they perceive as overly intellectual, uninteresting, or body-denying, or as needing to be enriched by insights from other religions. ${ }^{43}$ But, worried by non-Christian roots, they Christianize these practices. Father Thomas Ryan, director of the Paulist North American Office for Ecumenical Interfaith Relations, is a certified Kripalu yoga instructor who envisions "yoga prayer" sacramentally as a way to "pray with your whole body." Ryan interprets yoga as superior to Christian ascetic disciplines or the valorization of physical suffering as sanctifying the spirit; in his view, yoga reveals that "salvation doesn't mean getting out of this skin, [but] rather being transfigured and glorified in it." ${ }^{44}$ Evangelicalsaptly characterized by the historian Mark Noll as culturally adaptive, biblically experiential Christians-replace non-Christian with Christian language and religion-neutralizing references to scientific studies. ${ }^{45}$ Christian yoga and Christian alternatives to yoga appear to solve the dilemma of how to access non-Christian spiritual resources while remaining a faithful Christian.

The label "Christian yoga" functions, first, to mark an intention to repurpose a practice for Christian uses and, second, to market a product to Christian consumers. The initial step is to add Christian identifiers. For example, there is Christ Centered Yoga ${ }^{46}$ Yahweh Yoga,${ }^{47}$ and Christoga. ${ }^{48}$ Some programs take linguistic separation a step further by subtracting the word "yoga"given its connotation of "yoking with the divine"-and insist on the nonequivalence of yoga with "alternatives" such as Outstretched in Worship, ${ }^{49}$ WholyFit, ${ }^{50}$ and PraiseMoves. ${ }^{51}$ Such programs reflect core evangelical

\footnotetext{
${ }^{43}$ Christopher R. Armstrong, Medieval Wisdom for Modern Christians: Finding Authentic Faith in a Forgotten Age with C. S. Lewis (Grand Rapids, Mich.: Brazos, 2016), 4-5.

${ }^{44}$ Thomas Ryan, Prayer of Heart and Body: Meditation and Yoga as Christian Spiritual Practice (Mahwah, N.J.: Paulist, 2001), n.p.; and Thomas Ryan, Yoga Prayer: An Embodied Christian Spiritual Practice, dir. Barbara M. Gangi (Boulder, Co.: Sounds True, 2004), video, 91 minutes.

${ }^{45}$ Mark A. Noll, American Evangelical Christianity: An Introduction (Malden, Mass.: Blackwell, 2000), 2.

${ }^{46}$ Becky Martin, Christ Centered Yoga, accessed August 13, 2018, https://christcenteredyoga. $\mathrm{com} /$.

${ }^{47}$ Deanna Smothers and Courtney Chalfant, Yahweh Yoga, accessed August 13, 2018, http:// yahwehyoga.com/.

${ }^{48}$ Janine Turner with Mary Cunningham, "Christoga: Christian Yoga,” YouTube (video), posted September 14, 2007, https://www.youtube.com/watch?v=PpcYPiE6A1s.

${ }^{49}$ Susan Bordenkircher, Outstretched in Worship: A Christian Approach to Yoga (n.p.: Medical Media Services, 2002), DVD.

${ }^{50}$ Laura Monica, WholyFit, accessed August 13, 2018, http://www.wholyfit.com/.

${ }^{51}$ Laurette Willis, PraiseMoves, accessed August 13, 2018, https://praisemoves.com/; and Bhanu Bhatnagar, "Who Owns Yoga?" Al Jazeera Correspondent, November 27, 2014, https://www. aljazeera.com/programmes/aljazeeracorrespondent/2014/11/who-owns-yoga-20141117114315748275. html. See time segment 17:37-20:18.
} 
concerns identified by the historian David Bebbington: biblicism through biblical framing, activism in energetically recruiting others, conversionism by insisting that programs draw participants closer to Christ, and crucicentricism in the sense of dedicating Sun Salutations to the Son, Jesus. ${ }^{52}$

Evangelical adaptations of yoga and the creation of yoga alternatives presume that practices can be Christianized through linguistic substitution. Sun Salutations are christened "Son Salutations." ${ }^{\text {"3 }}$ To begin: "Stretch your arms ... overhead into Praise Hands. Reach your heart and arms to Heaven, sending your greeting to Jesus." End in "Prayer Position (hands at heart center)," the fourth of seven chakras, "feeling the movement of energy." 54 Classes close with "Corpse Pose," resting in "God's grace." 55 Prānāyāma, controlled breathing to circulate impersonal vital energy, is reimagined as "breathing in the Holy Spirit." ${ }^{\text {"N }}$ Namaste is retranslated: "The image of God in me honors the image of God in you." The mantra Om may be replaced by Shalom. Evangelicals typically add Bible verses and prayers to traditional poses or relabel them with Christian references, such as Prodigal Son, Noah's Arch, Lazarus, Holy Rollers, Eagle, Angel, Rainbow, and Altar. Rarely, programs add new poses, as with the Jewish Aleph-Bet Yoga's emulation of Hebrew alphabet letters. ${ }^{57}$

Most Americans, including Christians, know little about the history of yoga or South Asian religions. ${ }^{58}$ Lack of knowledge stems in part from fear that learning about other religions leads to doctrinal error. (Evangelical students in my religious studies classes disclose parental concerns that I will indoctrinate them in pluralism.) Paradoxically, fear of learning about religions can make it more likely that Christians will engage in practices of the religions that worry them.

By evangelical logic, if someone dedicates a practice to Jesus, it is by definition Christian. It is difficult to refute testimonial claims like that of Christianity Today writer Agnieszka Tennant: "The three hours a week I spend doing yoga ... draw me closer to Christ. They are my bodily-kinetic

\footnotetext{
${ }^{52}$ David W. Bebbington, Evangelicalism in Modern Britain: A History from the 1730s to the 1980s (London: Unwin Hyman, 1989), 2-17.

${ }^{53}$ Susan Roesser, "Son Salutation Yoga," accessed August 13, 2018, http://www.sonsalutation. $\mathrm{com} /$.

${ }^{54}$ Luke Frederick, "Holy Yoga 101 Workshop Outline," Holy Yoga, updated March 16, 2017, https://holyyoga.net/resources/holy-yoga-101-information-packet/, 9-10.

${ }^{55}$ Ibid., 25.

${ }^{56}$ Susan Bordenkircher, Yoga for Christians: A Christ-Centered Approach to Physical and Spiritual Health through Yoga (Nashville: Thomas Nelson, 2006), 3, 8, 17.

${ }^{57}$ Steven A. Rap, Aleph-Bet Yoga: Embodying the Hebrew Letters for Physical and Spiritual Well-Being (Woodstock, Vt.: Jewish Lights, 2002).

${ }^{58}$ Stephen Prothero, Religious Literacy: What Every American Needs to Know-And Doesn't (New York: HarperCollins, 2008).
} 
prayer." ${ }^{59}$ An Amazon.com customer purchased a Christoga DVD "because I was worried that my prayer life was lacking. This is an excellent way to incorporate Christ's Word into your soul. ${ }^{, 60}$ Christians who see no problem with Christoga's amalgamation of Christian and Hindu beliefs and practices do worry that it is immodest for Christian yogini Janine Turner to reveal her belly button. ${ }^{61}$ PraiseMoves elicits less criticism from evangelicals in part because founder Laurette Willis tucks her blouse into her leggings. ${ }^{62}$ Holy Yoga developer Brooke Boon summarily dismisses criticisms by insisting on her evangelical identity: "Remember that in Holy Yoga, the answer to practically every question is two words: Jesus Christ." ${ }^{, 63}$ Claiming devotion to Jesus is the ultimate evangelical argument stopper.

Does explicitly Christian yoga lead people toward the kinds of spirituality associated with traditional yoga? Holy Yoga is among the most popular Christian yoga programs with 1,700 certified instructors. While attendees at the January 2018 American Society of Church History annual meeting were participating in conference sessions, Holy Yoga was hosting a four-hour "Holy Yoga Experience" in thirty-six cities to share its "Christ-honoring experience." ${ }^{64}$ Holy Yoga reinterprets Christian doctrine by incorporating beliefs from South Asian religions. Holy Yoga instructor training requires study of "classical" yoga moral and ethical codes, including yamas and niyamas from the Yoga Sütras. ${ }^{65}$ Instructors convey to students that $O m$ is the "vibrational sound of the universe" that "creates" and combines "energies" in yoga classmates. Prayer "does the same thing" as chanting $O m$ because "Jesus the Word of God . . . is the vibration" that God used in speaking the universe into creation. God created humans as "physical and energetic beings," and "chakras" are "energy centers" that "echo what God

\footnotetext{
${ }^{59}$ Agnieszka Tennant, "Yes to Yoga: Can a Christian Breathe Air that has been Offered to Idols?," Christianity Today, May 19, 2005, http://www.christianitytoday.com/ct/2005/mayweb-only/42.0b. html.

${ }^{60}$ Becca, "Build Spiritual and Physical Strength with Christoga," Amazon (customer review), posted March 13, 2008, https://www.amazon.com/Christoga-Faith-Fitness-Janine-Turner/product-reviews/ B000R9SK1U/ref=cm_cr_arp_d_paging_btm_next_2?ie=UTF8\&reviewerType $=$ avp_only_reviews\& sortBy=recent\&pageNumber $=\overline{2}$.

${ }^{61}$ Kindle Customer, "Great Workout from a Beginner's Point of View," Amazon (customer review), posted March 27, 2009, https://www.amazon.com/Christoga-Faith-Fitness-JanineTurner/dp/B000R9SK1U.

${ }^{62}$ Laurette Willis, PraiseMoves: The Christian Alternative to Yoga (Eugene, Ore.: Harvest House, 2006), DVD.

${ }^{63}$ Brooke Boon, Holy Yoga: Exercise for the Christian Body and Soul (New York: FaithWords, 2007), 38

${ }^{64}$ Holy Yoga, “The Holy Yoga Experience, Saturday, January 6th, 2018,” accessed December 17, 2017, https://holyyoga.net/hyexperience/.

${ }^{65}$ Holy Yoga, Masters Instructor Training, accessed August 13, 2018, https://holyyoga.net/ training/masters/, 6,8 .
} 
has created. ${ }^{.66}$ Brooke Boon attests that traditional yoga beliefs about energy, $O m$, and chakras "make sense to me." Such beliefs may come to make sense to other Holy Yoga participants, who may also become more likely to explore traditional yoga. Psychological research on branding shows empirically that "brand extension advertising facilitates parent brand recall." "parent brand" and Holy Yoga is a "brand extension," then favorable experience with Holy Yoga may facilitate favorable reception of the parent brand - traditional yoga and associated concepts.

Christian yogis react defensively to criticism because they get something from yoga that they do not get from other forms of exercise or church. When President Albert Mohler of the Southern Baptist Theological Seminary voiced "surprise" at Christian commitment to yoga in a 2010 Associated Press interview, several hundred Christian readers sent Mohler angry e-mails. ${ }^{68}$ One "devoted Southern Baptist church member" explained: "I get much more out of yoga and meditation than I ever get out of a sermon in church." 69

Many Americans have come to perceive church as irrelevant, boring, or worse. Not only is there a rise in the number of religious "Nones" but also a groundswell of religious "Dones" - the most committed, theologically orthodox church members who are leaving church because it seems more of a hindrance than a help to spiritual growth and service. ${ }^{70}$ Some have sought revitalization by: converting to Roman Catholicism or Orthodoxy; gravitating toward an innovative emerging church; trading soporific sermons for streamlined megachurch productions; seeking intimate, authentic community in a house church; or enrolling in a School of Supernatural Ministry, where classes include personal prophecy, healing the sick, and Raising the Dead $101 .^{71}$ And others have taken up yoga. As

\footnotetext{
${ }^{66}$ Brooke Boon, “'To Om or not to Om': Christian Yoga Daily Meditation with Brooke Boon Founder of Holy Yoga," YouTube (video), posted June 16, 2012, https://www.youtube.com/ watch?v=82eQg6WHMJg; and Frederick, "Holy Yoga 101," 7.

${ }^{67}$ Maureen Morrin, "The Impact of Brand Extensions on Parent Brand Memory Structures and Retrieval Processes," Journal of Marketing Research 36, no. 4 (November 1999): 517.

${ }^{68}$ Albert Mohler, "Yahoo, Yoga, and Yours Truly," updated October 7, 2010, www.albertmohler. com/2010/10/07/yahoo-yoga-and-yours-truly.

${ }^{69} \mathrm{E}-\mathrm{mail}$, quoted in Mohler, "Yahoo."

${ }^{70}$ Pew Research Center, "Nones' on the Rise: One-in-Five Adults Have No Religious Affiliation," The Pew Forum on Religion \& Public Life (Washington, D.C.: Pew Research Center, 2012), http://www.pewforum.org/files/2012/10/NonesOnTheRise-full.pdf; and Gary Nguyen, "You've Heard of the Religious 'Nones': Here are the Religious 'Dones," World Religion News, August 20, 2015, http://www.worldreligionnews.com/issues/youve-heard-of-thereligious-nones-here-are-the-religious-dones.

${ }^{71}$ Armstrong, "Sound, Style, Substance," 77-86; and Molly Hensely-Clancy, "Meet the 'Young Saints' of Bethel Who Go to College to Perform Miracles," BuzzFeedNews, October 12, 2017, https://www.buzzfeed.com/mollyhensleyclancy/meet-the-young-saints-of-bethel-who-go-to-collegeto?utm_term=.ytvmXeVRa\#.rp1vrY8MO.
} 
one Christian yogi notes, "The churches are emptying; the yoga centers are full." 72

Yoga has not only entered Christian subcultures but also the American mainstream, as epitomized by nominally secular, public-school yoga programs. These programs have polarized Christians, and they reveal how Christians can, ironically, contribute to their own marginalization.

\section{Public-School Yoga}

The first American public schools provided Christian religious and moral instruction. The Massachusetts Bay Colony passed a school law in 1642 to ensure that all children received a "good education" that instilled "principles of Religion" and inoculated youth against growing "rude, stubborn \& unruly.",73 Nineteenth-century common schools promoted "nonsectarian" instruction that avoided denominational doctrines while teaching religious values presumed to be "universal" (though distinctively Protestant) deemed necessary to moral character and civic virtue. ${ }^{74}$ In the mid-twentieth century, the Supreme Court prohibited public schools from promoting prayer and Bible reading, interpreting these practices as violating the Establishment Clause of the First Amendment to the U.S. Constitution. ${ }^{75}$ Protestants inadvertently paved the way for these court rulings by opposing funding for Catholic parochial schools. ${ }^{76}$ Since the late twentieth century, educational reformers have increasingly envisioned yoga and meditation as filling a perceived moral void in non-religious, and thus constitutionally permissible, ways.

Public-school yoga and meditation programs are proliferating. A 2015 survey identified thirty-six U.S. school-based yoga programs (fifteen of which require Yoga Alliance certification) that have trained 5,400 instructors and offer yoga in 940 schools. $^{77}$ Well over a million public-school students

\footnotetext{
${ }^{72}$ Casey Rock, "Voices from the Mat," in Reclaiming the Body in Christian Spirituality, ed. Thomas Ryan (New York: Paulist, 2004), 96.

${ }^{73}$ Nathaniel B. Shurtleff, ed., Records of the Governor and Company of Massachusetts Bay, 1628-1686, vol. 2 (Boston: W. White, 1853-1854), 203, 607; and B. Edward McClellan, Moral Education in America: Schools and the Shaping of Character from Colonial Times to the Present (New York: Teachers College Press, 1999), 5.

${ }^{74}$ Steven K. Green, The Bible, the School, and the Constitution: The Clash that Shaped Modern Church-State Doctrine (New York: Oxford University Press, 2012), 20-23.

${ }^{75}$ Sarah Barringer Gordon, The Spirit of the Law: Religious Voices and the Constitution in Modern America (Cambridge, Mass.: Harvard University Press, 2010), 86.

${ }^{76}$ Ibid., 84; Green, The Bible, the School, and the Constitution, 5-7, 255; and Philip Hamburger, Separation of Church and State (Cambridge, Mass.: Harvard University Press, 2004), 446, 479.

${ }^{77}$ Bethany Butzer, Marina Ebert, Shirley Telles, and Sat Bir Singh Khalsa, "School-based Yoga Programs in the United States: A Survey," Advances in Mind-Body Medicine 29, no. 4 (Fall 2015): $18-26$.
} 
have received instruction in mindfulness meditation or Transcendental Meditation. ${ }^{78}$

The introduction of yoga and meditation into public schools reflects a perceived crisis in American education that Christianity has, by many accounts, failed to solve. ${ }^{79}$ Program advocates cite statistics on school shootings; single-parent homes; child depression, suicide, drug abuse, obesity, and pregnancy; and worries about underachievement, technology overdose, and an epidemic of unkind, judgmental attitudes and behaviors. Nominally secular yoga promises not only to trim and fit flabby young bodies but also to instill values and cultivate character.

\section{Ashtanga Yoga in the Encinitas Union School District}

The Indian Hindu Shri Krishna Pattabhi Jois (1915-2009) developed modern Ashtanga (Aștāinga), or eight-limbed, yoga in Mysore, India. The eight limbs are: (1) yama (moral restraint), (2) niyama (ethical observance), (3) āsana (posture), (4) prāṇāyāma (breath control), (5) pratyahara (calm mind), (6) dhāraṇa (attention), (7) dhyāna (meditation), and (8) samādhi ("union with the Supreme," that is, Brahman —or, in Jois's words, becoming "one with God"). ${ }^{80}$

Jois focused his teaching on the third limb, äsanas, or postures, because he was confident that practitioners would inevitably experience all eight limbs. According to Jois, "Anyone" who practices will "experience God inside," and "the love of God will develop . . . whether they want it or not." Beginning in the 1970 s, Westerners traveled to India to study with Jois. In 1975, Jois's student David Williams brought him to Encinitas in San Diego County, California - a city claimed for yoga in 1937 by Yogananda's

\footnotetext{
${ }^{78}$ Jon Kabat-Zinn, "Too Early to Tell: The Potential Impact and Challenges - Ethical and Otherwise - Inherent in the Mainstreaming of Dharma in an Increasingly Dystopian World," Mindfulness 8, no. 5 (October 2017): 1130; Mary Sykes Wylie, "The Mindfulness Explosion," Psychotherapy Networker 39, no. 1 (January/February 2015): 19; Elissa Strauss, "Being Mindful About Mindfulness," Slate, March 2, 2016, http://www.slate.com/articles/double_x/family/2016/03/teaching_mindfulness_meditation in schools_a skeptic_s_investigation.html; Mindful Schools, "Home," accessed August 13, 2018, http://www.mindfulschools.org/; The Hawn Foundation, MindUP Curriculum: Grades PreK-2: Brain-Focused Strategies for Learning — and Living (New York: Scholastic, 2011); and David Lynch Foundation, "Quiet Time Changes Lives," accessed August 13, 2018, https://www.david lynchfoundation.org/schools.html.

${ }^{79}$ Jane Naomi Iwamura, Virtual Orientalism: Asian Religions and American Popular Culture (New York: Oxford University Press, 2011), 20.

${ }^{80}$ Sri K. Pattabhi Jois, Yoga Mala (New York: North Point Press, 2010), 6, 16.

${ }^{81}$ Sri K. Pattabhi Jois, quoted in R. Alexander Medin, "3 Gurus, 48 Questions: Matching Interviews with Sri T. K. V. Desikachar, Sri B. K. S. Iyengar \& Sri K. Pattabhi Jois," ed. Deirdre Summerbell, Namarupa (Fall 2004): 18, italics mine.
} 
building of a Self-Realization Fellowship ashram. ${ }^{82}$ After visiting Encinitas, Pattabhi Jois returned home, but his son, Manju, took up residence to teach yoga; Manju's wife Nancy taught kindergarten in the Encinitas Union School District (EUSD). ${ }^{83}$

One of Pattabhi Jois's devotees, Sonia Jones, wife of hedge fund billionaire Paul Tudor Jones, founded Jois Yoga in 2008 "in Loving Dedication" to her guru, and in 2011 she incorporated Jois Yoga's nonprofit counterpart, the K. P. Jois USA Foundation. ${ }^{84}$ The Foundation's "mission" was "to bring the philosophy, teachings, and values of Sri K. Pattabhi Jois" to "youths in underserved communities" by funding school yoga and supporting "changes in public policy" to require "yoga and meditation competency in public education credentialing" and mandate yoga and meditation in all classrooms. $^{85}$ The Foundation began by giving EUSD $\$ 4$ million to codevelop a district-wide Ashtanga yoga program taught by Foundationselected, trained, and supervised teachers and to coauthor a curriculum for the Foundation to use in other districts. ${ }^{86}$

When in 2013 Christian parents sued EUSD for allegedly promoting Hinduism through yoga, administrators overcame the legal challenge by adopting a characteristically evangelical strategy: relabeling "Ashtanga yoga" as "EUSD yoga" and subtracting Sanskrit terminology and "cultural

\footnotetext{
${ }^{82}$ David Williams, interview by Guy Donahaye and Eddie Stern, Guruji: A Portrait of Sri K. Pattabhi Jois Through the Eyes of His Students (New York: North Point, 2010), 17, 19; Yogananda, Autobiography of a Yogi (New York: Philosophical Library, 1946); and Downtown Encinitas MainStreet Association, 2011 Downtown Encinitas Directory, https://web.archive.org/ web/20121114154819/https://www.encinitas101.com/wp-content/uploads/2011/04/ENC1.pdf, 15.

${ }^{83}$ Cynthia Gray, "Declaration,” May 9, 2013, 2:11-12, in Sedlock.

${ }^{84}$ Jois Yoga, “About Jois,” October 8, 2011, http://web.archive.org/web/20110926221753/http:// www.joisyoga.com/about.html; and K. P. Jois USA Foundation, Inc., Form 990-EZ, Short Form Return of Organization Exempt From Income Tax, 2011, http://pdfs.citizenaudit.org/ 2012_12_EO/45-3182571_990EZ_201112.pdf.

${ }^{85}$ Jois Yoga, "Story," accessed August 13, 2018, http://joisyoga.com/about/story/; and Sonima Health and Wellness Foundation, Inc., Form 990 Return of Organization Exempt From Income Tax, 2012, http://pdfs.citizenaudit.org/2013_12_EO/45-3182571_990_201212.pdf, 2, Schedule I, Rider to Schedule O.

${ }^{86}$ Sonima Foundation Form 990 Return of Organization Exempt From Income Tax, 2013, https:// projects.propublica.org/nonprofits/organizations/453182571, 2, Rider to Schedule O; Sonima Foundation, Form 990 Return of Organization Exempt From Income Tax, 2014, http://pdfs. citizenaudit.org/2015_12_EO/45-3182571_990_201412.pdf, Schedule I; "Memorandum of Understanding between Encinitas Union School District and Regur Development Group Solutions," 2015-2016, removed December 7, 2017-March 23, 2018, http://encinitasparents4truth.com/wpcontent/uploads/2016/06/EUSD-RDG-MOU-for-2015-16.pdf; and "Sonima / EUSD Health and Wellness Program Memorandum of Understanding 2015-2016," removed August 4, 2016November, 17, 2017, http://webcache.googleusercontent.com/search?q=cache:NjBo424p7LIJ:ww2. eusd.net/board/Documents/Board\%2520ATtachments/Sonima\%2520MOU\%25202015-2016.pdf +\&cd $=12 \& \mathrm{hl}=\mathrm{en} \& \mathrm{ct}=\mathrm{clnk} \& \mathrm{gl}=\mathrm{us}$. For details on the Foundation's involvement with the EUSD yoga curriculum, see Brown, Debating Yoga and Mindfulness.
} 
references.. ${ }^{\circ 7}$ I obtained a bird's eye view of this trial by serving as an expert witness after the plaintiffs asked me to explain the contested meanings of religion and Ashtanga yoga. Despite some linguistic repackaging, at the time of trial, EUSD children were still using Sanskrit terms, such as Namaste (often translated "the Divine in me bows to the Divine in you") and Savāsana (or Corpse) ${ }^{88}$ Students were forming circles with their thumb and forefinger in wisdom gesture (jñanna mudrā), symbolic of subordinating the individual spirit (Ätman) to Universal Spirit (Brahman), and chanting $\mathrm{Om}$ (often identified as the "sound of the divine"). ${ }^{89}$ Children were also putting their palms together in front of their chest in prayer position (añjali mudrā) and closing their eyes to meditate while sitting in Lotus, or Padmāsana, with one or both feet above the knees. ${ }^{90}$ The judge was persuaded that Lotus had been defanged by renaming it "criss-cross applesauce," although videos reveal teachers saying "Lotus," and the curriculum never uses the phrase "criss-cross applesauce" but uses "Lotus" 194 times. ${ }^{91}$ As of 2018, EUSD yoga, like Ashtanga yoga, "always begins" with Opening Sequence A, Sürya Namaskāra, established by Jois as a "prayer to the sun god," Surya. EUSD classes still always finish with Lotus and Rest, postures explained in EUSD's pilot-year textbook as facilitating "concentration, meditation, and ultimately Samadhi.",92

Emboldened by the Encinitas victory, the Jois Foundation rolled out its curriculum nationally and internationally, rebranded as Sonima (a portmanteau from founder Sonia Jones and associate Salima Ruffin) and then as Pure Edge (which shares an abbreviation with Physical Education, PE, but also evokes Ashtanga's virtue of purification, or tapas, from the niyamas). By 2016, the Foundation had taught yoga and meditation to over 40,000 children in 114 partner schools in nine school districts and six U.S. regions - as well as the country of Kenya - and had convinced the

\footnotetext{
${ }^{87}$ John S. Meyer, "Statement of Decision," July 1, 2013 (oral), September 23, 2013 (final), 11:9, 11:15, 11:20-22, in Sedlock.

${ }^{88}$ Sheetal Shah, "A Victory for US Schoolchildren through a Faulty Understanding of Yoga," Firstpost, April 19, 2015, http://www.firstpost.com/world/victory-us-schoolchildren-faultyunderstanding-yoga-2202856.html; and Alanna Kaivalya and Arjuna van der Kooij, Myths of the Asanas: The Stories at the Heart of the Yoga Tradition (San Rafael, Calif:: Mandala, 2010), 28.

${ }^{89}$ Gregor Maehle, Ashtanga Yoga: Practice \& Philosophy (Novato, Calif:: New World Library, 2006), 127; and Yvonne L. Banuet-Alvers, Yoga the College Way: A Textbook for College Yoga (Dubuque: Kendall/Hunt, 1996), 77.

${ }^{90}$ Meyer, "Decision," 11:20-22.

${ }^{91}$ Ibid., 9:8-9; Regur Development Group, "EUSD Yoga," video 3 of 4, March 2013, in Sedlock; and EUSD, On the Mat, May 2013, in Sedlock.

${ }^{92}$ K. Pattabhi Jois Ashtanga Yoga Institute, “Traditional Method," accessed August 13, 2018, http://sharathjois.com/the-practice/traditional-method/; K. Pattabhi Jois, quoted in "Wisdom of the Masters: Fourteen Distinguished Figures in the Yoga World Offer Advice to Those Starting Out on the Yoga Path as well as to Seasoned Practitioners," Yoga Journal 122 (June 1995): 64; and Kaivalya and Kooij, Myths of the Asanas, 18-22.
} 
New York legislature to pass a resolution establishing a "Health and Wellness Week."93

Most challenged school districts have, like EUSD, permitted parents to opt their children out of yoga and meditation. Such allowances depend upon implicit acknowledgment that such programs are arguably religious. Most schools do not allow opting out of math or dodge ball, and classroom teachers are not always allowed to opt out of school-wide yoga and meditation. For example, teachers in British Columbia and California have lost their classrooms for refusing to teach the MindUp mindfulness curriculum. ${ }^{94}$ Certain well-funded school yoga and meditation proponents have publicly articulated agendas for making their programs mandatory. Pattabhi Jois urged making "yogasana, the Surya Namaskara, and their traditions compulsory for all students in all educational institutions." 95 The Jois/Sonima/Pure Edge Foundation's public policy goal is to make yoga and meditation a requirement for teacher credentialing and "an essential component of the education system." 96 Actress and movie producer Goldie Hawn's "mission" is to get MindUP into "every school" - and "absolutely mandated." "97 The Calmer Choice mindfulness curriculum is intended as a "universal" intervention that every student is "expected to attend. Math, science, history, mindfulness, and English . . . [just] part of their day." 98 By not effectively opposing or even supporting yoga and meditation, Christians may unknowingly facilitate a move toward mandatory programs.

\section{Yoga Culture Wars}

The Encinitas controversy sheds light on a tense relationship between yoga and Christianity in American culture. Encinitas is a religiously divided community. As a New York Times article observed in 2012, EUSD "serves the liberal beach neighborhoods ... as well as more conservative inland communities. On the

\footnotetext{
${ }^{93}$ Sonima Foundation, "In the Community,” accessed August 13, 2018, http://web.archive.org/ web/20160918104335/http://www.sonimafoundation.org/community/; and Sonima Foundation, "NY State Legislators Pass Resolution Declaring First Week in May 'NY Health and Wellness Week," May 4, 2015, https://web.archive.org/web/20160327015942/http://www.sonimafoundation. org/ny-state-legislators-pass-resolution-declaring-first-week-in-may-ny-health-and-wellness-week/.

${ }_{94}$ Informant e-mail to author, February 10, 2014; and Angela Draper, "Remove Mandatory MindUp/Mindfulness from My Classroom," iPetitions, updated October 16, 2017, https://www. ipetitions.com/petition/remove-mindfulness-classroom.

${ }^{95}$ Jois, Yoga Mala, 41-42, italics mine.

${ }^{96}$ Sonima Foundation, Form 990, 2012, Schedule O, italics mine.

${ }^{97}$ Goldie Hawn, quoted in Marianne Schnall, 'Goldie Hawn Talks 'MindUP' and Her Mission to Bring Children Happiness,” Huffington Post, April 20, 2011, http://www.huffingtonpost.com/ marianne-schnall/goldie-hawn-mindup_b_850226.html.

${ }^{98}$ Fiona Jensen, "A Note from Fiona," Instructor Training Manual: Pre-K through Grade 2/3 (unpublished 2nd draft, Calmer Choice, 2015), 3.
} 
coast, bumper stickers reading 'Keep Leucadia Funky' are borne proudly. Farther inland, cars are more likely to feature the Christian fish symbol, and large evangelical congregations play an important role." ${ }^{99}$ When the Sedlock v. Baird yoga lawsuit went to trial in 2013, 45 percent of Encinitas residents practiced yoga - compared with a 9 percent national average. ${ }^{100}$ Although 40 percent of the Encinitas population identified as Christian (compared with 70 percent nationally), only one Christian family, Jennifer and Stephen Sedlock, stepped forward as petitioners. ${ }^{101}$ Six other Christian families submitted legal declarations, and 269 signatories (at least one of whom was Hindu) added their voices of protest to an online petition. ${ }^{102}$ Although more Christians than the Sedlocks objected to EUSD yoga, most of them had personal reasons for not wanting to become a lightning rod in a public controversy. Fewer than 1 percent of EUSD parents opted their children out of yoga, which comprised a majority of state-mandated PE minutes. ${ }^{103}$ Other Christian parents knew or cared little about the yoga program, or else they wanted to join in.

The Sedlocks were represented pro bono by a theologically and politically conservative evangelical Christian attorney, Dean Broyles, whose nonprofit law practice, The National Center for Law \& Policy, promotes "religious freedom, the sanctity of life, traditional marriage, parental rights, and other civil liberties." ${ }^{104}$ Alliance Defending Freedom (ADF) - an international legal nonprofit with religious priorities similar to Broyles's - awarded a grant of $\$ 9,000$ for court costs and lent assistance from a senior litigator; a local Christian attorney also offered time pro bono. ${ }^{105}$ Broyles's strategy was to argue that EUSD yoga violates the Establishment Clause by promoting certain types of religion while inhibiting others. Broyles had trouble getting financial support from Christian legal organizations that worry about the Establishment Clause being used against Christians and/or still hope to get

\footnotetext{
${ }^{99}$ Will Carless, "Yoga Class Draws a Religious Protest," New York Times, December 15, 2012, http://www.nytimes.com/2012/12/16/us/school-yoga-class-draws-religious-protest-from-christians. html? r $=0$.

${ }^{100}$ Downtown Encinitas MainStreet Association, 2011 Downtown Encinitas Directory, 15.

${ }^{101}$ Sperling's Best Places, "Encinitas, California: Religion," accessed August 13, 2018, http:// www.bestplaces.net/religion/city/california/encinitas.

${ }^{102}$ Mary Eady, "Remove the Ashtanga Yoga Program from EUSD," iPetitions, accessed August 13, 2018, https://web.archive.org/web/20121208134335/http://www.ipetitions.com:80/petition/ remove-the-ashtanga-yoga-program-from-eusd/signatures/page/5; and https://www.ipetitions.com/ petition/remove-the-ashtanga-yoga-program-from-eusd/.

${ }^{103}$ EUSD, "Health \& Wellness Program Frequently Asked Questions (FAQs)," May 25, 2016, updated September 14, 2016, http://www.eusd.net/wp-content/uploads/2016/12/EUSD-Healthand-Wellness-FAQs-Update-9-14-16.pdf.

${ }^{104}$ Dean R. Broyles, "National Center for Law \& Policy,” accessed August 13, 2018, http://www. nclplaw.org/about-us/dean-broyles/.

${ }^{105}$ Alliance Defending Freedom, "Who We Are," accessed August 13, 2018, https://www. adflegal.org/about-us.
} 
prayer back into schools. ${ }^{106}$ One reason the petitioners did not appeal to the California Supreme Court is that they ran out of funds.

Although many school yoga and meditation programs have spawned complaints - often from Christians, but also from Hindus, Buddhists, and atheists - Sedlock remains the only high-profile litigation. ${ }^{107}$ Given the close associations of yoga and meditation with Hinduism, Buddhism, and other religious and spiritual traditions, it is less surprising that there are Christian protestors than that their ranks are thin. Since Sedlock, I regularly receive cold-contact e-mails from Christians across the U.S. and Canada who are worried about yoga or meditation in their local schools - and frustrated in their efforts to convince school officials, or even other Christians, that the programs are religious or conflict with Christianity. One of the most striking features of these e-mails is the theme of isolation: these are Christians who feel like they are the only ones who care. A father from Virginia recounted that pastors "tell me how misinformed I am" to consider that mindfulness might be religious: "Thanks for listening. I feel like I'm alone here."108 An Ohio father bemoaned the "indifference (and even defensiveness) of many Christians."109 A mother and pastor in New York was "baffled by the utter apathy" of school officials and Christian parents who refused to read the information she sent them before discounting her concerns. ${ }^{110}$ These complainants are the "embattled" evangelicals described by the sociologist Christian Smith. They are confident in the "moral superiority" of their opposition to yoga and meditation, but, finding little traction from their "personal influence strategy," they feel that American culture, including large swaths of Christian culture, has rejected their warnings and consigned them personally to the status of "second-class" citizens, unwelcome in the public square. $^{111}$

Such Christians lament their woes to any who will lend a sympathetic ear, but they rarely lobby to change laws or enlist help from courts to enforce laws. Exhibiting a tendency that Smith dubs "voluntaristic absolutism," evangelicals call the nation to conform to Christian ideals yet resist collective action because they want compliance to be voluntary, effected

\footnotetext{
${ }^{106}$ Dean R. Broyles, interviewed by author, June 12, 2015.

${ }^{107}$ The Pennsylvania Charter Appeal Board rescinded a charter for a yoga-based school in Education for New Generations Charter School v. North Penn School District, CAB No. 201310 (2016).

${ }^{108}$ Informant e-mail to author, April 21, 2016.

${ }^{109}$ Informant e-mail to author, December 1, 2014.

${ }^{110}$ Informant e-mails to author, January 17, 2017, and January 30, 2017.

${ }^{111}$ Christian Smith, with Michael Emerson, Sally Gallagher, Paul Kennedy, and David Sikkink, American Evangelicalism: Embattled and Thriving (Chicago: University of Chicago Press, 1998), xi, 129, 187, 140 .
} 
through one-on-one persuasion. ${ }^{112}$ Christians who have sought legal representation report difficulties finding attorneys willing to take their case or raising funds to litigate. ${ }^{113}$

Christians who do form a united front have had somewhat more success in influencing school boards. When in 2014 a school district in Bloomington, Indiana, proposed introducing MindUP, a coalition of twelve pastors banded together. The school board tabled the proposal once they realized that it could incite a financially costly exodus of Christians from the public schools. ${ }^{114}$ Yet, three years later, one district school started teaching mindfulness, this time without informing parents. ${ }^{115}$

Non-evangelical school administrators are rarely persuaded by pleas of religious discrimination, particularly when issued by wealthy, white Protestants like the Sedlocks. Many non-evangelicals regret the long history of Protestant dominance in U.S. cultural institutions, especially since even Supreme Court rulings have not fully disestablished Protestantism from public schools. ${ }^{116}$ Evangelicals who want prayer but not yoga may be denounced as judgmental and hypocritical. Christian critics do not help their case by complaining vaguely that yoga is "inherently" religious. Such critics sense religious tension at a gut level but lack knowledge or vocabulary to explain why yoga violates their conscience. This makes critics susceptible to charges of "yogaphobia."117 Comparing pro-yoga and anti-yoga social media, e-mail listservs, and websites reveals that critics cite fewer academic sources, articulate less nuanced arguments, and make more typographical and grammatical errors.

The inability of Christian critics to elucidate their concerns reflects an educational disparity. National surveys indicate that evangelicals have somewhat lower educational attainments than the general population; 20 percent of evangelicals are college educated as compared with 27 percent of the total adult population. Hindus and Buddhists have higher attainments,

\footnotetext{
${ }^{112}$ Ibid., 210. Smith insightfully observes that the same tendencies are a source of evangelical "thriving" and relative ineffectiveness in influencing the broader culture.

${ }^{113}$ Michael Woodruff, quoted in Sarah Barringer Gordon, "The New Age and the New Law: Malnak v. Yogi, Transcendental Meditation and the Definition of Religion," in Law and Religion: Cases in Context, ed. L. C. Griffin (New York: Wolters Kluwer, 2010), 19 of draft version; and informant e-mail to author, November 24, 2015.

${ }^{114}$ Field notes, Monroe County Community School Corporation Board Meeting, December 16, 2014.

${ }^{115}$ Jackson Creek Middle School, "Lesson \#1-August: What is Stress, Mindfulness," Stress Management Curriculum, (unpublished lesson manuscript, August 2017).

${ }^{116}$ Mark A. Chancey, "A Textbook Example of the Christian Right: The National Council on Bible Curriculum in Public Schools," Journal of the American Academy of Religion 75, no. 3 (September 2007): 554-581.

${ }^{117}$ Andrea R. Jain, Selling Yoga: from Counterculture to Pop Culture (New York: Oxford University Press, 2015), 130.
} 
with 77 percent and 47 percent, respectively, being college educated. ${ }^{118}$ During the Sedlock trial, not only the opposing attorneys but even the judge mocked the plaintiffs for "wear[ing] their religion on their sleeve" as they haltingly attempted "trial by Wikipedia."119 Today's situation may recall the "Scopes Monkey Trial" of 1925, in which Fundamentalist Christians technically won a court case challenging evolution-but opponents disparaged them as intellectually and religiously backwards. ${ }^{120}$ Modern evangelicals are better educated than their Fundamentalist predecessors, but many lack training for yoga culture wars. Evangelicals are poorly equipped to engage reflectively with popular culture because most lack interest in rigorous historical and theological study that could pinpoint continuities and discontinuities with Christian traditions.

\section{Cultural Appropriation and Cultural Imperialism}

Christians have long struggled to present themselves and their message to cultural outsiders in winsome ways. Activist evangelicals are particularly zealous to share what they envision as good news that others need for temporal happiness and eternal salvation. Yet it is difficult to preach Christ without being perceived by audiences as disrespecting their cultures. Christian yoga and public-school yoga may exacerbate intercultural tensions. Promoters of Christian and secular yoga face the twin charges of cultural appropriation and cultural imperialism.

Hindu spokespersons blame yoga popularizers for distorting yoga. Although certain Indian Hindu yogis, famously Vivekananda and Yogananda, have recruited Americans and vaunted yoga as bridging cultural divides, other Hindus express dismay at American reinterpretations. ${ }^{121}$ In 2008, the Hindu American Foundation initiated a "Take Back Yoga" campaign, calling for public acknowledgment that yoga is rooted in Hinduism. ${ }^{122}$ Indian American

\footnotetext{
${ }^{118}$ Barry A. Kosmin and Ariela Keysar, The American Religious Identification Survey (ARIS 2008): Summary Report (Hartford, Conn.: Trinity College, 2009), 16 (e-book), accessed online April 16 2018, https://commons.trincoll.edu/aris/publications/2008-2/aris-2008-summary-report/; and Pew Research Center, "Educational Attainment of U.S. Religious Groups," posted November 4, 2016, http://www.pewresearch.org/fact-tank/2016/11/04/the-most-and-least-educatedu-s-religious-groups/ft_16-10-06_educationreligiousgroups/.

${ }^{119}$ David Peck, in Sedlock transcript, May 20, 2013, 33:25-34:1; and Meyer, "Decision," 18:1824, 19:4-5.

${ }^{120}$ Michael Lienesch, In the Beginning: Fundamentalism, the Scopes Trial, and the Making of the Antievolution Movement (Chapel Hill: University of North Carolina Press, 2007), 52.

${ }^{121}$ Diana Eck, A New Religious America: How a "Christian Country" Has Become the World's Most Religiously Diverse Nation (New York: HarperCollins, 2001), 100, 105.

${ }^{122}$ Hindu American Foundation, "Take Back Yoga: Bringing to Light Yoga's Hindu Roots," accessed August 13, 2018, http://www.hafsite.org/media/pr/takeyogaback.
} 
yoga teacher Susanna Barkataki argues that when "someone from the dominant culture" teaches yoga without acknowledging "the roots of the practices, they are culturally appropriating yoga," using their "power" to "exploit" South Asian "cultural riches." 223 Answering the thorny question "Who owns yoga?" Subhas Tiwari of Hindu University of America insists that yoga "originated" in "Hindu culture"; he dubs Christian yoga "religious schizophrenia." "124 Yogi Baba Prem alleges that Christian yogis are "secretly" practicing "Hinduism without having to renounce their Christian tradition." 125

Denying that anyone owns yoga, evangelists for Christian or secular yoga may unthinkingly impose yoga on other cultural groups. Public-school programs target low-income African Americans and Latinos, whom promoters view as lacking virtues instilled by yoga. A 2012 article in Teaching Tolerance: A Project of the Southern Poverty Law Center lauds a Title I Atlanta school that uses yoga to quell "bickering" and "fussing," and as a "strategy for proactively managing classroom behavior." ${ }^{\text {" } 26 ~ I n ~ 2013, ~ t h e ~}$ Sonima Foundation funded Ashtanga yoga in New York City public schools "comprised of minority youth," mostly "Black" or "Hispanic." 27 The justification for a 2010 yoga study in Baltimore schools attended by African American, "mixed race," and Latino children is that "youth in underserved, urban communities are at risk for a range of negative outcomes," are "chronically stressed," and need help "enhancing self-regulatory capacities." 128 Implicit is a racial narrative in which people of color are "at risk" because they have lesser "self-regulatory capacities," and a religious narrative in which Christian practices have failed America's children. ${ }^{129}$

The supposed beneficiaries of philanthropically-funded yoga may already have cherished religious resources to cope with life's challenges. African

\footnotetext{
${ }^{123}$ Susanna Barkataki, "Is My Yoga Cultural Appropriation? What to Do About It," Huffington Post, February 9, 2016, http://www.huffingtonpost.com/susanna-barkataki/is-my-yoga-culturalappro_b_9191342.html.

${ }^{124}$ Subhas Tiwari, "Yoga Renamed Is Still Hindu," Hinduism Today (January/February/March 2006), https://www.hinduismtoday.com/modules/smartsection/item.php?itemid=1456.

${ }^{125}$ Yogi Baba Prem, "There is No Christian Yoga," Speaking Tree (blog), updated August 20, 2013, https://www.speakingtree.in/blog/there-is-no-christian-yoga.

${ }^{126}$ Lisa Ann Williamson, "Yoga in Public Schools," Teaching Tolerance: A Project of the Southern Poverty Law Center 42 (Fall 2012): 27-28.

${ }^{127}$ Ericka Mellon, "HISD Hopes Yoga Classes Will Boost Students' Health," Houston Chronicle, September 22, 2014, http://www.houstonchronicle.com/news/education/article/HISD-hopes-yogaclasses-will-boost-students-5773381.php; and Donna Wang and Marshall Hagins, "Perceived Benefits of Yoga among Urban School Students: A Qualitative Analysis," Evidence-Based Complementary and Alternative Medicine (January 18, 2016): 2.

${ }^{128}$ Tamar Mendelson, Mark T. Greenberg, Jacinda K. Dariotis, Laura Feagans Gould, Brittany Rhoades Cooper, and Philip J. Leaf, "Feasibility and Preliminary Outcomes of a School-Based Mindfulness Intervention for Urban Youth," Journal of Abnormal Child Psychology 38, no. 7 (October 2010): 985.

${ }^{129}$ Iwamura, Virtual Orientalism, 20.
} 
American and Latino communities are statistically more religiously activeand predominantly Christian - than the Caucasian populations who typically fund and administer programs. ${ }^{130}$ One Spanish-speaking Catholic woman from El Salvador withdrew from a yoga study for "religious reasons," complaining that the "teachers' beliefs were being imposed on her" and that a statue of Patañjali seemed "diabolic." ${ }^{\text {"131 }}$ Christian and secular yoga may not only alienate certain South Asian Hindus who decry cultural theft but also African American and Latino Christians bequeathed yoga.

\section{CONCLUSION}

Yoga exemplifies the fraught relationship between Christianity and American culture. Wheaton College's effort to redeem yoga through linguistic substitution reflects a perception that church traditions have grown stale. Ashtanga yoga in the Encinitas Union School District and the specter of mandatory yoga are emblematic of divisions among Christians, the frustration of many Americans with Protestant dominance, and a broad-based pursuit of moral cultivation through yoga spirituality. Naive to how practices can change beliefs, culturally adaptive evangelicals feel embattled by others, yet they undercut their own professed beliefs, contribute to their own marginalization, and participate in processes deemed cultural appropriation and cultural imperialism that hinder their evangelistic goals. In the final analysis, Christian Yoga may be nothing new under the sun (or Son), but it may usher in a new era in the relationship between Christianity and culture.

\footnotetext{
${ }^{130}$ Kosmin and Keysar, American Religious Identification Survey, 14.

${ }^{131}$ Kimberly R. Middleton, Regina Andrade, Steffany Haaz Moonaz, Charlene Muhammad, and Gwenyth R. Wallen, "Yoga Research and Spirituality: A Case Study Discussion," International Journal of Yoga Therapy 25, no. 1 (2015): 33-35.
} 